\title{
Simulations of Cellulose Synthesis Initiation and Termination in Bacteria
}

Hui Yang${ }^{1}$, John McManus², Daniel Oehme ${ }^{3}$, Abhishek Singh ${ }^{4}$, Yaroslava G. Yingling ${ }^{4}$, Ming Tien $^{2}$, James D. Kubicki ${ }^{3 *}$

1 Department of Biology, The Pennsylvania State University, University Park, PA 16802, United States 2 Department of Biochemistry and Molecular Biology, The Pennsylvania State University, PA 16802, United States

3 Department of Geological Sciences, University of Texas at El Paso, El Paso, TX, United States

4 Department of Materials Science and Engineering, North Carolina State University, Raleigh, North Carolina 27695, United States

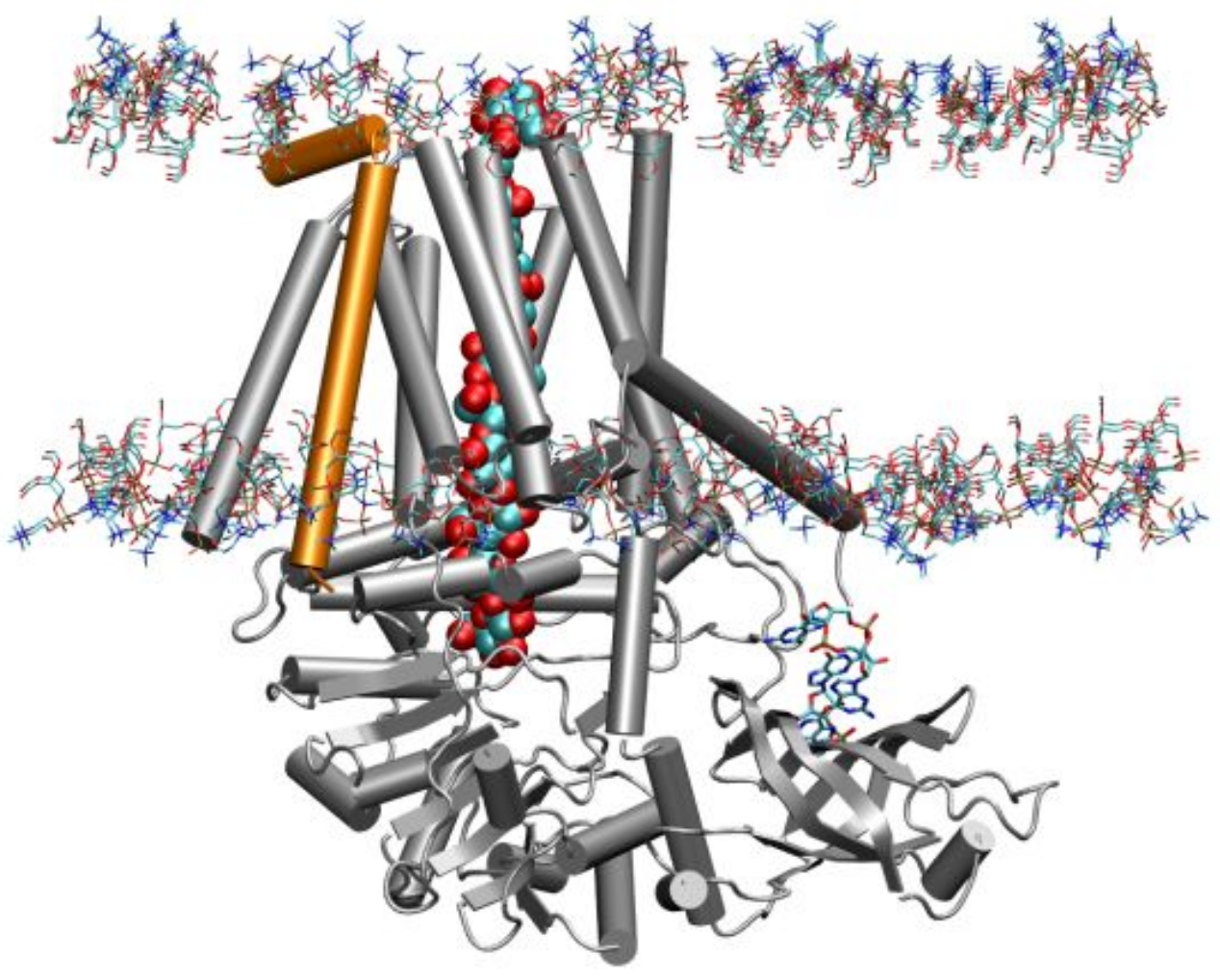

Figure S1. The enzyme system contains a cyclic di-GMP bound BcsA, BcsB (TM anchor, colored in gold) and a cellulose chain with eleven glucose units. (PDB entry: 4P02). $\mathrm{H}_{2} \mathrm{O}$ molecules and hydrophobic tails of POPC are not shown. 


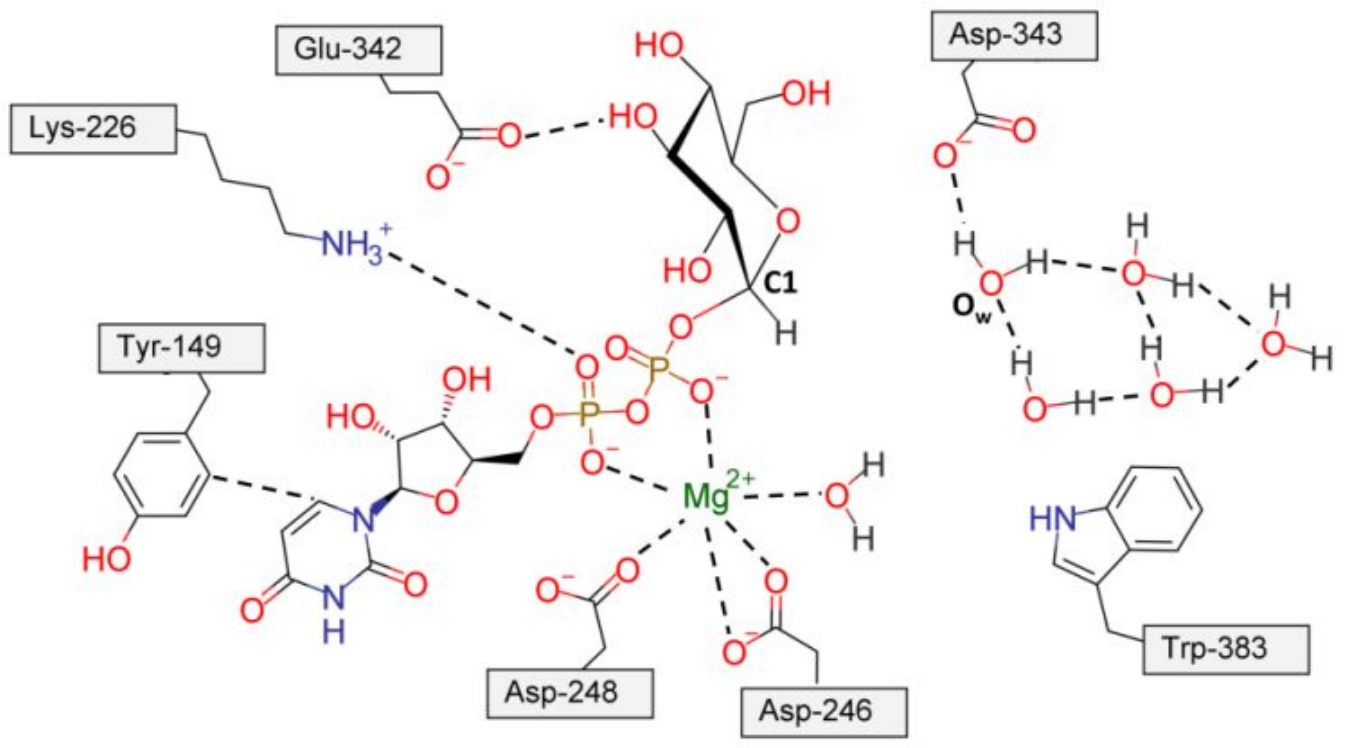

Figure S2. The QM layer of the QM/MM model of cellulose synthesis initiation contains UDPa-D-Glc, $\mathrm{Mg}^{2+}$, one $\mathrm{H}_{2} \mathrm{O}$ molecule coordinated with $\mathrm{Mg}^{2+}$, and the side chains of seven residues (Glu342, Lys226, Tyr149, Asp246, Asp248, Trp383 and Asp343) involved in the catalytic reaction or binding with the substrate. The QM layer was treated at the M05-2X/6-31G(d) level of theory. The MM layer (the entire system) is treated by the AMBER force field.

Table S1. Relevant Geometric Parameters for Enzyme-Substrate, Enzyme-Product, and Transition State Complex Models Obtained by QM/MM Calculations.

\begin{tabular}{|c|c|c|c|c|c|c|c|}
\hline & & \multicolumn{2}{|c|}{ enzyme-substrate } & \multicolumn{2}{|c|}{ enzyme-TS } & \multicolumn{2}{|c|}{ enzyme-product } \\
\hline & & initiation & elongation ${ }^{\mathrm{a}}$ & initiation & elongation $^{\mathrm{a}}$ & initiation & elongation $^{\mathrm{a}}$ \\
\hline \multirow{4}{*}{$\begin{array}{c}\text { Distance } \\
(\AA ̊)\end{array}$} & $\mathrm{O}_{\mathrm{D} 343}-\mathrm{H}_{4}$ & 1.7 & 1.6 & 1.5 & 1.5 & 1.0 & 1.0 \\
\hline & $\mathrm{O}_{\mathrm{w}}-\mathrm{H}_{\mathrm{w}}$ & 1.0 & 1.0 & 1.0 & 1.0 & 1.6 & 1.9 \\
\hline & $\mathrm{O}_{1}-\mathrm{C}_{1}$ & 1.4 & 1.4 & 2.8 & 1.7 & 3.1 & 2.9 \\
\hline & $\mathrm{O}_{\mathrm{w}}-\mathrm{C}_{1}$ & 3.5 & 3.4 & 2.1 & 2.1 & 1.5 & 1.5 \\
\hline \multirow[t]{3}{*}{ Angle $\left(^{\circ}\right)$} & $\mathrm{H}_{1}-\mathrm{C}_{1}-\mathrm{C}_{2}$ & 109.0 & 109.5 & 119.1 & 122.1 & 113.4 & 113.1 \\
\hline & $\mathrm{C}_{2}-\mathrm{C}_{1}-\mathrm{O}_{5}$ & 111.4 & 112.1 & 121.9 & 115.7 & 111.2 & 112.1 \\
\hline & $\mathrm{O}_{5}-\mathrm{C}_{1}-\mathrm{H}_{1}$ & 107.4 & 115.2 & 116.4 & 115.5 & 110.5 & 112.2 \\
\hline
\end{tabular}

a: data from ref $^{1}$ 


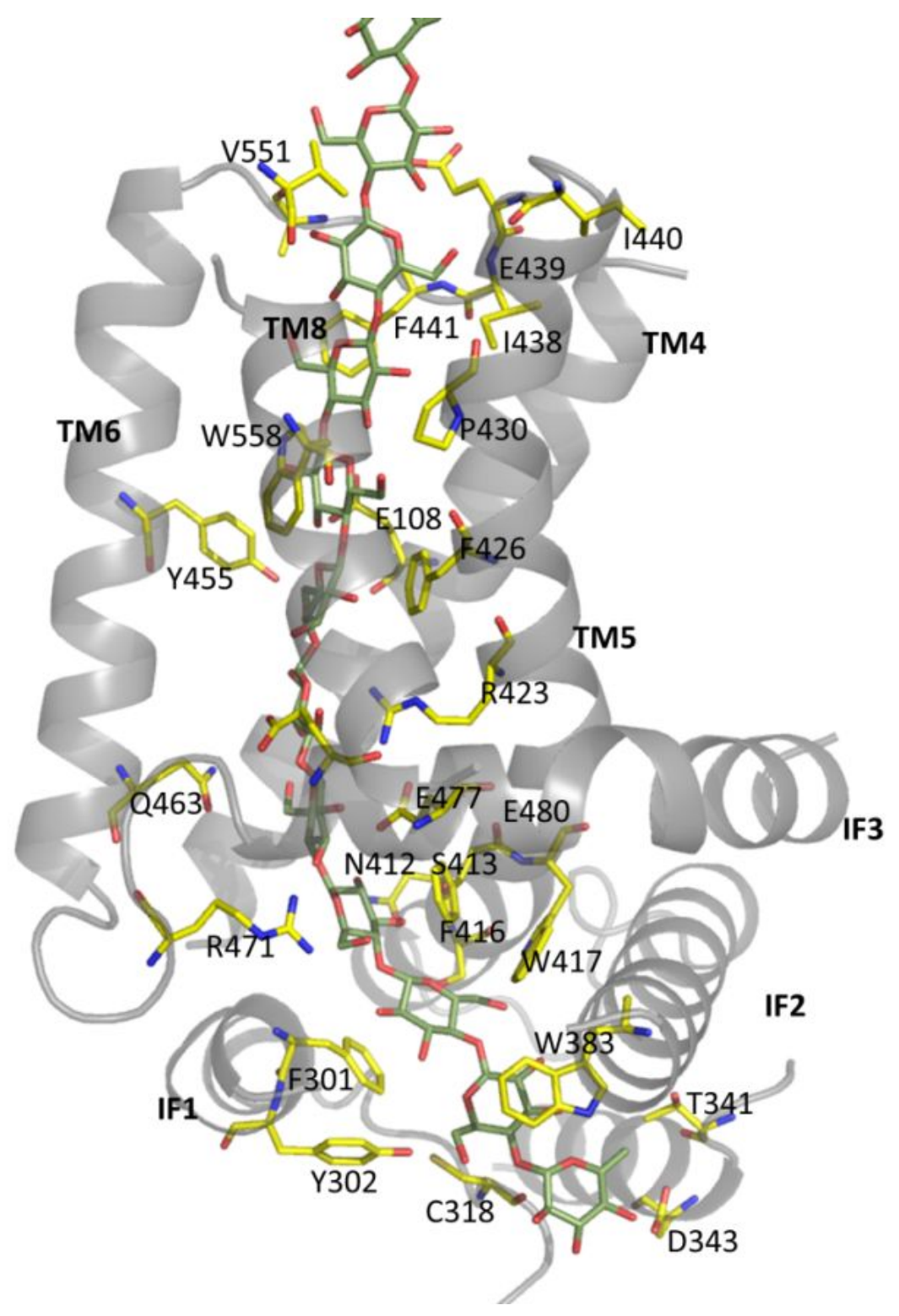

Figure S3. Residues within $4 \AA$ of the glucan chain in the exit tunnel of BcsA.

\section{References}

1. Yang, H.; Zimmer, J.; Yingling, Y. G.; Kubicki, J. D., How cellulose elongates - A QM/MM study of the molecular mechanism of cellulose polymerization in bacterial CESA. The Journal of Physical Chemistry B 2015, 119 (22), 6525-6535. 